\title{
WYKORZYSTANIE W POLSCE ENERGII WIATRU DO OŚWIETLANIA I OGRZEWANIA
}

\begin{abstract}
W artykule przedstawiono różne rodzaje budowy elektrowni wiatrowych wykorzystywane do produkcji własnego prądu elektrycznego, ogrzewania pomieszczeń, gospodarstwa rolnego. Przedstawiono charakterystyki warunków wiatrowych w Polsce, a także wady i zalety elektrowni wiatrowych.
\end{abstract}

Słowa kluczowe: wykorzystanie energii wiatru, elektrownie wiatrowe, charakterystyka wietrzności

\section{Wprowadzenie}

W porównaniu z krajami europejskimi, zwłaszcza takimi jak Niemcy albo Dania, Polska niedawno zaczęła swoją przygodę $\mathrm{z}$ energetyką wiatrową. W ostatnich latach nastapił wzrost zainstalowanych mocy farm wiatrowych o 166 razy w porównaniu z 2000 r. Według danych Urzędu Regulacji Energetyki moc zainstalowana w energetyce wiatrowej w Polsce w latach 2008-2010 siegała $666 \mathrm{MW}$, przy czym główne inwestycje wiatrowe są zbudowane w centralnej Polsce, w rejonie Karpat oraz w pasie wybrzeża Bałtyku. Przełomowy w energetyce był 2008 r., w którym nastapił 40-procentowy przyrost liczby projektów związanych $\mathrm{z}$ energią odnawialną. $\mathrm{W}$ tym też roku największy nacisk położono na inwestycje w energetykę wiatrową, na którą przypada 36\%, czyli $8500 \mathrm{MW}$ spośród 24000 MW wszystkich mocy wytwórczych.

Możliwości rozwoju energetyki wiatrowej w Polsce są dość obiecujące, na co wskazują wyniki badań wieloletnich kierunków i prędkości wiatru, prowadzonych w ramach sieci meteorologicznej Instytutu Meteorologii i Gospodarki Wodnej. Uprzywilejowanymi w Polsce rejonami pod względem zasobów wiatru są:

- środkowe, najbardziej wysunięte na północ części wybrzeża od Koszalina po Hel,

- rejon wyspy Wolin,

- Suwalszczyzna,

- środkowa Wielkopolska i Mazowsze, 
- Beskid Śląski i Żywiecki,

- Bieszczady i Pogórze Dynowskie.

\section{Budowa elektrowni wiatrowych}

\subsection{Budowa elektrowni wiatrowych do produkcji własnego prądu elektrycznego}

Elektrownie wiatrowe do pracy w sieci wydzielonej są stosowane w dwóch przypadkach: gdy obiekt przeznaczony do zasilania znajduje się poza zasięgiem sieci energetycznej lub gdy inwestor chce wykorzystać elektrownie do ogrzewania. Elektrownie wiatrowe współpracujące z siecią wydzieloną są bardziej złożone niż współpracujące $\mathrm{z}$ siecią energetyki zawodowej. Stosowane w nich generatory synchroniczne samowzbudne są znacznie droższe i bardziej zawodne, niż asynchroniczne generatory pracujące w sieci. Ponadto elektrownie, aby zapewnić ciągłość dostaw energii, muszą pracować w złożonym systemie. System ten powinien zawierać co najmniej:

- elektrownię wiatrową,

- baterie akumulatorów odpowiedniej wielkości,

- regulator ładowania baterii,

- przetwornicę napięcia stałego na zmienne,

- oporowy odbiornik nadwyżki energii.

Aby polepszyć całość systemu, wskazane jest jego połączenie $\mathrm{z}$ baterią ogniw fotowoltaicznych. Takie skojarzenie pomaga wyrównać dostawy energii w ciągu roku. Dobrze jest też przewidzieć dodatkowe, rezerwowe źródło zasilania w postaci automatycznie uruchamianego agregatu spalinowego. Oczywiście niezbędne jest nadzorowanie całości przez komputerowy system sterowania. System taki opracowuje się indywidualnie dla każdego obiektu. Kluczem do poprawnego doboru elementów są dane dotyczące charakterystyki zapotrzebowania obiektu na energię elektryczną [1].

\subsection{Budowa elektrowni wiatrowych do ogrzewania pomieszczeń}

W obecnych warunkach pomysł ogrzewania domu za pomocą elektrowni wiatrowych jest bardzo trudny do uzasadnienia ekonomicznego i nieopłacalny. Jeśli zatem chce się wykorzystać wiatr do ogrzewania domu, to lepiej najpierw sprzedać energię do zakładu energetycznego, a za otrzymane środki kupić paliwo do ogrzewania. Należy jednak dodać, że projektanci często wracają do tego tematu i być może wraz z rozwojem technologii energetyki wiatrowej nastąi przełom. Elektrownia wiatrowa będzie mogła jednak funkcjonować tylko w skojarzeniu z innym źródłem energii. 
Ciagły wzrost cen energii elektrycznej i paliw kopalnianych oraz wyczerpywanie się ich zasobów zmuszają do poszukiwania innych sposobów ogrzewania budynków. W niektórych przypadkach zastosowanie mogłyby znaleźć elektrownie wiatrowe. Takie elektrownie mogą całkowicie zaspokoić zapotrzebowanie na energię i uniezależnić obiekt od zakładu energetycznego. Budowa elektrowni wiatrowej jest opłacalna, szczególnie tam, gdzie doprowadzanie energii z zakładu jest kosztowne. Elektrownie te są coraz bardziej popularne i wszystko wskazuje na to, że zainteresowanie nimi w przyszłości jeszcze się zwiększy. Koncepcja wykorzystania energii wytworzonej przez elektrownie wiatrowe do celów grzewczych polega na konwersji energii elektrycznej na ciepło i akumulację ciepła w materiałach ceramicznych. Do wyprodukowania energii potrzebnej do ogrzania budynku czy wody jest potrzebna elektrownia wiatrowa o nominalnej mocy ok. $8 \mathrm{~kW}$. Elektrownia wiatrowa musi zazwyczaj współpracować z krajowym systemem energetycznym. Gdy elektrownia wyprodukuje nadmiar energii, to jest ona odprowadzana do krajowego systemu, natomiast gdy występuje jej niedobór, to jest do odkupienia. Zastosowanie akumulowania energii umożliwia sprzedawanie energii po cenach wyższych, a odkupywanie po cenach niższych [2].

Działanie elektrowni wiatrowych może być przyczyną pojawiania się różnego rodzaju problemów. Są one związane m.in. z poprawnym prowadzeniem pracy innych jednostek wytwórczych, regulacją napięcia i mocy biernej, zmianą poziomu mocy zwarciowej, wpływem na pracę zabezpieczeń, stabilnością systemu, pogorszeniem parametrów jakości energii. Duże zagęszczenie źródeł wiatrowych na pewnym obszarze może np. prowadzić do pojawienia się trudności z utrzymaniem stabilności napięciowej, zmianą rozpływów mocy w sieci i przepływów, wymianą międzyobszarową i międzysystemową, powstawaniem ,wąskich gardeł" w sieci rozdzielczej i przesyłowej itp. Problemy te mogą być szczególnie zauważalne w sytuacji, gdy źródła energii wiatru są rozmieszczone w systemie nierównomiernie do warunków geograficzno-klimatycznych, a system już istniejący na obszarach o szczególnie korzystnych warunkach wiatrowych jest słabo rozwinięty [3].

\subsection{Zastosowanie silowni wiatrowej w gospodarstwie rolnym}

Siłownie wiatrowe mają ciagle niewielkie zastosowanie w gospodarstwach rolnych. Siłownie takie były często stosowane przed pierwszą wojną światową. Wykorzystywano je głównie do napędu pompy wodnej, wytwarzania energii elektrycznej i napędzania młynów zbożowych do czasu elektryfikacji wsi.

W gospodarstwach wiejskich, w procesach rolniczych oraz drobnym przemyśle usytuowanym na terenach wiejskich, energia wiatru może być wykorzystywana do:

- ogrzewania pomieszczeń inwentarskich i domowych,

- ogrzewania wody technologicznej i wody dla gospodarstw domowych, 
- napędu urządzeń technologicznych i innych, np. wentylatorów do osuszania ziarna i siana, urządzeń do przygotowania pasz,

- napędu pomp wodnych w nawadnianiu i odpompowywaniu wód,

- napędu kompresorów do natleniania wód w zbiornikach chowu ryb.

Korzyściami gospodarczymi i ekologicznymi wynikającymi z budowy i eksploatacji siłowni wiatrowej są:

- nieograniczone zasoby energii wiatru,

- krótki okres budowy i montażu,

- możliwość budowy elektrowni o mocy do 20 kVA niedużym kosztem, tzw. systemem gospodarczym,

- brak szkodliwych zanieczyszczeń w produkcji energii elektrycznej,

- 2/3 rocznej produkcji energii elektrycznej z energii wiatru uzyskuje się w sezonie grzewczym (od listopada do marca).

\subsection{Zastosowanie silowni wiatrowej do ogrzewania pomieszczeń}

Zastosowanie siłowni wiatrowej do ogrzewania pomieszczeń nie różni się od innego zastosowania elektrowni wiatrowej. Zainstalowanie elektrowni nawet niewielkiej mocy wiąże się jednak ze znacznymi nakładami finansowymi. $\mathrm{Z}$ tego powodu większość siłowni wiatrowych stosowanych do ogrzewania buduje się systemem gospodarczym, co znacznie obniża koszty. Zaletą takiego systemu jest niska cena budowy oraz brak konieczności ubiegania się o umowę z zakładem energetycznym. Wielkość projektu zależy od możliwości finansowych twórcy. Siłownia wiatrowa o osi poziomej składa się z wieży (najczęściej kratowej), wirnika (o różnej liczbie łopat zależnej od projektu), steru i prądnicy. Prądnica najczęściej o mocy 10-20 kW jest umieszczona w głowicy siłowni. Siłownię tego typu wybudowano w miejscowości Dubiecko. Użyto w niej prądnicy samowzbudnej 8-biegunowej, dostarczającej prąd o wysokim napięciu $380 \mathrm{~V}$. Prądnica ta w okresie grzewczym zasila system grzałek podgrzewających wodę w piecu akumulacyjnym, umieszczonym w piwnicy budynku. Do pieca akumulacyjnego jest też podłączony piec węglowy. Stworzenie takiego systemu ogrzewania dało właścicielowi $40 \%$ ciepła potrzebnego do ogrzania domu. W okresie letnim energia wiatru jest wykorzystywana do podgrzewania wody użytkowej. Profesjonalna elektrownia wiatrowa to taka, która została wyprodukowana w zakładzie specjalizującym się w tego typu inwestycjach i podłączona do sieci energetycznej. Na wybudowanie takiej elektrowni trzeba zgromadzić dużo środków finansowych oraz liczne dokumenty, zezwolenia, zaświadczenia, m.in. pozwolenie na budowę z właściwego urzędu gminy i umowę z zakładem energetycznym na przekazywanie nadwyżki energii. Inwestycja taka powinna się zwrócić w ciągu 7-8 lat. Urządzenie jest w pełni skomputeryzowane i nie potrzebuje żadnego dozoru pracownika. 
Inną możliwością wykorzystania małych siłowni wiatrowych są agregaty pompowe. Są one przeznaczone do pompowania, rekultywacji, napowietrzania zbiorników wodnych, szczególnie jezior, stawów rybnych oraz zbiorników stabilizacyjnych oczyszczalni ścieków. Urządzenia te powinny być stosowane tam, gdzie jest zachwiana równowaga biologiczna spowodowana zanieczyszczeniami chemicznymi, organicznymi, nadmiernym rozwojem glonów i roślinności wodnej. Urządzenia te powinny być stosowane tam, gdzie istnieje duże zapotrzebowanie na tlen ze względów ekologicznych, jak i technologicznych. Można tu zaliczyć także hodowlę ryb. Jak wynika z analizy ogólnych warunków wiatrowych, na całym obszarze Polski można instalować pompownie wiatrowe, jednak najbardziej korzystne warunki wiatrowe posiadają rejony północne i północnowschodnie.

\section{Mała elektrownia wiatrowa jako sposób na własny prąd}

Przydomowe elektrownie wiatrowe mogą służyć jako dodatkowe źródło energii, które w pewnym stopniu uniezależnia budynek mieszkalny (lub inny) od sieci energetycznej. Siłownie wiatrowe najczęściej sprawdzają się w przypadku domów niskoenergetycznych, bardzo dobrze ocieplonych, które potrzebują mniejszej ilości energii. Przydomowa elektrownia wiatrowa może dostarczać prąd na potrzeby odbiornika wydzielonego, czyli działającego niezależnie od sieci. Może nim być wydzielony obwód w domu, zwykle niskonapięciowy (np. obwód oświetleniowy czy obwód ogrzewania podłogowego), działający niezależnie od pozostałej instalacji $\mathrm{w}$ domu, zasilanej z konwencjonalnej sieci, bądź cała instalacja domowa odłączona od sieci elektroenergetycznej. Koszt budowy nowej elektrowni wiatrowej o mocy ok. $100 \mathrm{~W}$ wynosi 150 euro, czyli $600 \mathrm{zt}$, a elektrowni o mocy 2-3 kW - ok. $10200 \mathrm{zl}$. Im mniejsza moc elektrowni, tym zwykle dłuższy czas zwrotu poniesionych kosztów inwestycyjnych [4].

Aby podczas bezwietrznej pogody $\mathrm{z}$ elektrowni wiatrowej nie zabrakło energii, często stosuje się tzw. układy hybrydowe. Układ hybrydowy jest to np. połączenie elektrowni wiatrowej z panelem fotowoltaicznym lub tradycyjnym generatorem spalinowym. Ze względu na duże wahania mocy dostarczanej $\mathrm{z}$ elektrowni wiatrowych $\mathrm{w}$ układach hybrydowych konieczne jest stosowanie dodatkowych akumulatorów. Akumulatory takie umożliwiają gromadzenie energii w okresach zmniejszonego poboru i oddawanie jej w okresach zwiększonego poboru. Wybór wielkości typu oraz określonego rozwiązania elektrowni wiatrowej zależy od tego, czemu ma ona służyć. Elektrownia wiatrowa może wytwarzać prąd tylko i wyłącznie wtedy, gdy wieje wiatr i to z prędkością większą niż tzw. prędkość startowa, poniżej której turbina po prostu nie pracuje. Typowa elektrownia wiatrowa składa się z turbiny wiatrowej, akumulatora i przetwornicy. Przydomowe elektrownie wiatrowe są całkowicie niezależnymi źródłami energii, w których instaluje się albo prądnicę prądu stałego, albo małe 
trójfazowe asynchroniczne prądnice. Najczęściej są stosowane prądnice prądu stałego. Elektrownie z taką prądnicą mogą zasilać obiekt, jeżeli są wyposażone $\mathrm{w}$ regulator napięcia oraz akumulatory do gromadzenia energii, a jeśli mają dostarczać prą przemienny, muszą być wyposażone także w falownik. Jeśli elektrownia taka ma zasilać dom mieszkalny, to urządzenia składowe umieszcza się zazwyczaj w pomieszczeniach gospodarczych. Jeśli chodzi o podział elektrowni ze względu na moc, wyróżnia się mikro-, małe i duże elektrownie. Do zasilania domów stosuje się zazwyczaj dwa pierwsze rodzaje elektrowni.

Mikroelektrownie wiatrowe mają zazwyczaj moc mniejszą niż $100 \mathrm{~W}$. Używa się ich przede wszystkim do ładowania baterii akumulatorów, które stanowią zasilanie obwodów wydzielonych. Takie elektrownie można wykorzystywać do zasilania przez akumulatory części oświetlenia domu (pojedynczych lamp), a nawet poszczególnych pomieszczeń i urządzeń.

Małe elektrownie wiatrowe to modele nieco większe, o mocy od $100 \mathrm{~W}$ do $50 \mathrm{~kW}$. Mogą zapewniać energię elektryczną w pojedynczych gospodarstwach domowych czy też w małych firmach. W warunkach przydomowych najpopularniejsze są elektrownie o mocy od 3 do $5 \mathrm{~kW}$. Elektrownie tego typu wspomaga energia zmagazynowana $\mathrm{w}$ akumulatorach, która wystarcza do zasilania oświetlenia sprzętu i urządzeń domowych.

Duże elektrownie wiatrowe to $\mathrm{w}$ praktyce elektrownie o mocy powyżej $100 \mathrm{~kW}$. Są one stosowane przede wszystkim do wytwarzania prądu, który jest sprzedawany do sieci elektroenergetycznej. Taka elektrownia musi spełniać wszystkie wymogi lokalnego operatora sieci, potrzebna jest także zgoda na przyłączenie do sieci.

Ilość energii elektrycznej wyprodukowanej przez elektrownie zależy w głównej mierze od prędkości wiatru. Dobrze dobrana i usytuowana elektrownia może wytworzyć rocznie taką ilość energii elektrycznej, jaka odpowiada 10-20\% iloczynowi mocy normalnej zainstalowanej turbiny oraz liczbie godzin w ciągu całego roku ( 24 godziny na dobę). W tak liczonej wielkości uwzględnia się zarówno okresy bezwietrzne, jak i te z prędkością wiatru mniejszą od niezbędnej do produkcji mocy nominalnej przez elektrownię wiatrową. Szczegółowej oceny produkcji energii można dokonać dopiero po uwzględnieniu zasobów wietrzności w konkretnej lokalizacji oraz właściwości dobranego typu elektrowni wiatrowej.

\section{Charakterystyka wietrzności w Polsce}

Południowo-wschodni rejon Polski charakteryzuje się bardzo dużym potencjałem energetycznym wiatru, którego wartość wyliczona na podstawie wyników pomiarów w zakresie prędkości powyżej $4 \mathrm{~m} / \mathrm{s}$ na wysokości $30 \mathrm{~m} \mathrm{n.p.g.}$ wynosi ponad $2500 \mathrm{kWh} \cdot \mathrm{a} . \mathrm{Z}$ roku na rok w rejonie tym wzrasta zainteresowanie energią wiatru. Obecnie do Rzeszowskiego Zakładu Energetycznego energię 
elektryczną z wiatru dostarczają trzy firmy: elektrownia wiatrowa w Wróblisku Szlacheckim - gmina Rymanów, elektrownia w Pielgrzymce - gmina Osiek, wiatraki w Chwałowicach - gmina Radomyśl nad Sanem. Niedługo dołączą następne wiatraki z okolic Rymanowa. W gminie Dukla powstaje również projekt budowy dużej inwestycji tego typu. Elektrownie wiatrowe mają powstać także w okolicach Nowego Żmigrodu i Bukowska. Kolejne inwestycje tego typu są planowane głównie wzdłuż Beskidu Niskiego i Bieszczadów, ale także w okolicach Ropczyc, Mielca oraz Przemyśla. Dukielszczyzna i okolice Magurskiego Parku Narodowego to cenne krajobrazowo i przyrodniczo miejsca, więc instalowanie elektrowni wiatrowych $w$ tych rejonach może budzić zastrzeżenia. Równiny między Rzeszowem a Przemyślem to jednak także tereny dość wietrzne. W Pielgrzymce k. Jasła można zobaczyć jedną z takich elektrowni, w której skład wchodzą dwa wiatraki o mocy $75 \mathrm{~kW}$ każdy. Jest ona dobrym przykładem na to, jak nie niszcząc środowiska naturalnego, można uzyskać energię ze źródeł odnawialnych [5].

W Polsce energetyka wiatrowa rozwija się od kilkunastu lat. Pierwszy wiatrak postawiono w 1991 r., przy wcześniej już istniejącej Elektrowni Wodnej w Żarnowcu. Obecnie w miejscu tym znajduje się farma wiatrowa Lisewo. Pierwszą przemysłową farmę wiatrową w Polsce uruchomiono w Barzowicach (województwo zachodniopomorskie) w kwietniu $2001 \mathrm{r}$. Składała się ona z sześciu siłowni o łącznej mocy $5 \mathrm{MW}$, co dla Polski uznaje się za wartość minimalną dla wiatrowych farm o skali przemysłowej. W ostatnich latach w Polsce można zaobserwować bardzo szybki rozwój energetyki wiatrowej.

Moc zainstalowana w energetyce wiatrowej w Polsce to 1005 MW. Wśród inwestycji można wyróżnić 13 profesjonalnych projektów. Polska znajduje się na 24. miejscu w światowym rankingu producentów energii z wiatru z zainstalowaną mocą ok. $280 \mathrm{MW}$. Najwięcej energii wiatrowej wytwarzają Niemcy (moc ponad $22 \mathrm{GW}$ ), Stany Zjednoczone (16 GW) i Hiszpania (15 GW). Udział energii wiatrowej w całkowitym zapotrzebowaniu na energię jest najwyższy w Danii i wynosi ok. 20\%, w Hiszpanii - 9\%, w Niemczech - 7\%. Polska pokrywa energia wiatrową ok. $0,25 \%$ rocznego zapotrzebowania, a według rządowych prognoz udział ten ma do końca 2012 r. wzrosnąć dziesięciokrotnie i wynieść 2,3\% ogólnej produkcji energii. Zagęszczenie elektrowni wiatrowych w Polsce należy do najmniejszych w UE. Moc zainstalowana w energetyce wiatrowej na mieszkańca to $0,0037 \mathrm{~kW}$, a na $1 \mathrm{~km}$ obszaru lądowego - 0,45 kW. Łącznie w Polsce są posadowione 142 turbiny różnej mocy. Średnia moc takiej turbiny wynosi ok. 1,52 MW. Energia elektryczna w Polsce pochodzi w 94,7\% $\mathrm{z}$ węgla, w 2,6\% z gazu, w 2,4\% z elektrowni wodnych, w 0,3\% z innych źródeł. 


\section{Wady i zalety elektrowni wiatrowych}

Elektrownie wiatrowe pozwalają na pozyskiwanie energii z wykorzystaniem wiatru. Są to urządzenia zbudowane $z$ turbiny wiatrowej, za pomocą której produkują energię elektryczną. Elektrownie wiatrowe są uważane za jedną z lepszych możliwości ekologicznego pozyskania energii. Jednak oprócz licznych zalet, elektrownie takie mają też i wady.

Zalety elektrowni wiatrowych:

- brak konieczności stosowania paliwa do jej uruchomienia (jest więc uznawana za czystą ekologicznie),

- zmniejszenie emisji $\mathrm{CO}_{2}$ do atmosfery,

- możliwość zamontowania turbiny w miejscu oddalonym od krajowej sieci energetycznej,

- zmniejszenie kosztów energii elektrycznej przy turbinie w gospodarstwie domowym.

Wady elektrowni wiatrowych:

- mogą wpływać na klimat lokalny,

- mogą zmniejszać prędkość wiatru,

- wymuszają utrzymanie pewnej rezerwy mocy w tradycyjnych elektrowniach, gdyż są uzależnione od warunków pogodowych,

- są zagrożeniem dla ptaków - zabijają ptaki i zakłócają ich nawigację,

- szpecą krajobraz (szczególnie farmy wiatrowe), emitują hałas.

\section{Podsumowanie}

Rozwój energetyki odnawialnej, w tym także wiatrowej, jest możliwy jedynie przy odpowiednim wsparciu państwa. Specyfika tego wsparcia nie polega jednak na systemie przyznawania przez państwo ulg i zachęt, a na ustawowym zarządzeniu obowiązku zakupu lub wytworzenia energii elektrycznej pochodzącej ze źródeł odnawialnych i skojarzonych. Realizacja tego obowiązku stwarza dodatkowe koszty u podmiotów zobowiązanych do zakupu, i to wywołuje niechęć do jego wypełnienia.

Ceny energii elektrycznej będą się zwiększały przez najbliższe lata. Ze względu na duże koszty inwestycyjne w odnawialne źródła energii ustawodawca wprowadził zachęcające rozwiązanie dla producentów - dwa strumienie przychodów: ze sprzedaży energii i praw majątkowych wynikających ze świadectw pochodzenia wyprodukowanej energii. Kolejnymi zachętami i preferencjami, które powinny się przyczynić do rozwoju odnawialnych źródeł energii, są: 
- obniżenie o 50\% kosztów przyłączenia do sieci tego typu źródeł,

- wprowadzenie regulacji umożliwiających zastosowanie odmiennego sposobu bilansowania systemu elektroenergetycznego dla elektrowni wiatrowych,

- obowiązek zapewnienia przez operatora systemu elektroenergetycznego pierwszeństwa $\mathrm{w}$ świadczeniu usług przesyłowych energii wytworzonej w źródłach odnawialnych.

Obecne przychody wytwórców energii z odnawialnych źródeł są dwukrotnie wyższe niż z tradycyjnych nośników, gdyż cena sprzedaży do $1 \mathrm{MWh}$ energii tego typu przewyższa jej wartość. $Z$ tego wynika, że zainteresowanie odnawialnymi źródłami energii jest stosunkowo duże. Można przypuszczać, że jeżeli firmy z tej branży nie zaistnieją na rynku w najbliższych 3-4 latach, to trudno im będzie przyłączyć się do grona producentów elektrowni wiatrowych.

\section{Literatura}

[1] Ząber Z.: Możliwości wykorzystania energii wiatru w małych siłowniach wiatrowych oraz potencjału wody w małych elektrowniach wodnych, Czysta Energia, nr 10/2010, s. 30-31.

[2] Stanisz K.: Wykorzystanie energii wiatru do celów grzewczych. Porównanie z technologiami tradycyjnymi, Ciepłownictwo, Ogrzewnictwo, Wentylacja, nr 2/2008, s. 15-16.

[3] Bandzul W.: Polskie sieci elektroenergetyczne S.A. Elektrownie wiatrowe w Polsce, Elektroenergetyka, nr 3/2009, s. 17-21.

[4] Barzyk G., Grunwald M.: Sposób na własny prąd - elektrownia wiatrowa, Ładny Dom, nr 8/2006, s. 32-33.

[5] Tomasik T.: Wzrost zainteresowania banków projektami farm wiatrowych, Czysta Energia, nr 4/2009, s. 14.

\section{USING WIND POWER FOR LIGHTING AND HEATING IN ECONOMY OF POLAND}

S u m mary

The paper represents types of wind power stations to generate electric power purposed for heating and agriculture. It represents wind conditions of Poland and also advantages and disadvantages of using wind power stations.

Keywords: wind power using, wind power stations, wind conditions 